\title{
FRA REDAKSJONEN: TEMANUMMER OM YOGA OG MEDITASJON
}

Ordet yoga fremstår som nokså hverdagslig i moderne vestlige samfunn. Men hvordan forstås det, og av hvem? Yoga og meditasjon har lange røtter i østlige religiøse tradisjoner. I den vestlige kulturkretsen er dette fenomener med en kortere historie. Like fullt er det en interessant historie som både forteller om endringer i oppfatningen av hva «yoga» og «meditasjon» kan innebære, og om endrede holdninger til forholdsvis nye religiøse tradisjoner og praksiser. Yoga og meditasjon har utviklet seg fra å være relativt marginale fenomener i vestlige land, til å bli nærmest allestedsnærværende. Parallelt med økt utbredelse har oppfatningene av hva yoga og meditasjon er, og kan være, endret seg radikalt. Yoga tilbys i dag som sekulær treningsform på helsestudio, som metode for «selvutvikling» og som esoterisk praksis på nyåndelige samlinger.

Bidragene i dette temanummeret belyser noe av spennvidden som dekkes av begrepene yoga og meditasjon i dag. Johan Nilsson viser i sin artikkel hvordan svenske aktører tilknyttet den teosofiske bevegelsen bidro til å utvikle raja yoga som et system for åndelig utvikling. I tillegg til å analysere raja yoga spesifikt, belyser også artikkelen den helt sentrale rollen som nyreligiøse bevegelser, og især teosofien, hadde i å spre og utvikle yoga som et globalt fenomen.

Begrepet «yoga» brukes i dag også utover den indiske tradisjonen det har sitt utspring i. Tao Thykier Makeeff analyserer i sin artikkel hvordan «yoga» også formidles i forbindelse med kinesiske kroppsøvelser. Fredrik Gregorius beskriver utviklingen av «runeyoga», som henter inspirasjon både fra norrøne kilder og fra indisk yoga. Begge artiklene viser hvordan begrepene «yoga» og «meditasjon» har fătt et utvidet bruksområde, og peker også mot kraften begrepene har fått som merkevare og nøkkelord både i det nyåndelige feltet og i samfunnet ellers.

Yoga og meditasjon forstås på forskjellige måter, og det er stor spennvidde i hva som anses som målet med praksisen. Henriette Hanky viser i sin artikkel hvordan yogaretretter på Dharma Mountain markedsføres ulikt til ulike målgrupper. Overfor et allment publikum presenteres yoga som en vei til avspenning og velvære. For de som mer ak- 
tivt følger guruen Vasant Swaha, formidles derimot yoga og meditasjon som en vei til åndelig vekst.

Til sammen viser disse bidragene at begrepene yoga og meditasjon har fått et større bruksområde, og at de brukes kreativt i utviklingen av nye praksiser. Dette peker igjen mot begrepenes utvikling mot å bli del av nyreligiøsitetens lingua franca-og en del av det øvrige samfunnets hverdagsvokabular.

I 2020 gikk Aura over til åpen kildekode. Vi er stolte og glade over at artiklene som publiseres dermed blir lettere tilgjengelig, noe vi også ser på lesertallene. Erik Östling har gjort en fenomenal innsats for å legge ut eldre nummer av Aura på nettsidene. Snart vil hele arkivet være tilgjengelig på nett, forhåpentligvis til glede for både forfattere og lesere.

På vegne av redaktørene

Margrethe Løøv 